\title{
Genetic Divergence Studies in Brinjal (Solanum melongena L.) under Subtropical Plains of North-Western Himalayan Region
}

\author{
Anil Bhushan*, R. K. Samnotra and Sanjeev Kumar \\ Division of Vegetable Science \& Floriculture, FOA, Main Campus Chatha, SKUAST-Jammu \\ $J \& K-180009$, India \\ *Corresponding author
}

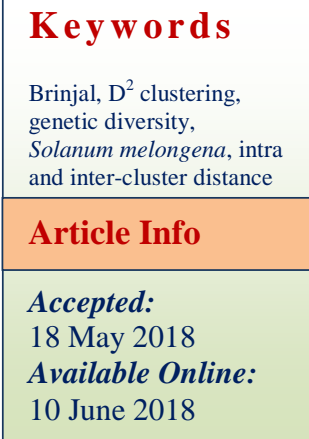

\section{Keywords}

Brinjal, $\mathrm{D}^{2}$ clustering, netic diversity, and inter-cluster distance

Accepted: Available Online: 10 June 2018

\section{A B S T R A C T}

Twenty five diverse genotypes of brinjal (Ten hybrids and fifteen open pollinated varieties) were evaluated for 20 different quantitative, qualitative and biotic stress traits in the experimental field of Division of Vegetable Science \& Floriculture, FOA, Chatha, SKUAST, Jammu during 2013-14 and 2014-15. The genotypes were grouped into six diverse clusters on the basis of $\mathrm{D}^{2}$ statistics. The clustering pattern suggested no association between genetic diversity and geographical diversity. Cluster VI accommodated maximum number of genotypes (7), followed by cluster III (5), cluster IV (4) and cluster V (4). Cluster III had maximum intra cluster distance (12.636), followed by cluster II (7.303) and cluster I (6.044), suggesting considerable genetic divergence among the genotypes of the respective clusters and the genotypes from within the clusters can be chosen as parents for any hybridization programme. The inter-cluster distance depicts greater divergence among the clusters and maximum inter-cluster was recorded between cluster IV and cluster VI (53.430) followed by cluster III and cluster IV (51.078) and cluster I and cluster III (36.610), suggesting greater diversity between genotypes belonging to respective pairs of clusters. For cluster mean values, the genotypes in cluster IV were having highest values for days to $50 \%$ flowering (55.39), days to first picking (77.14), number of fruits per plant (46.87), number of leaves per plant (56.98), number of primary branches (6.22), marketable yield per plant (1.70), fruit yield per plant (1.92), fruit yield per hectare (202.95), ascorbic acid content (13.55), total phenol content (1.25) and least mean values for shoot borer infestation (8.73), fruit borer infestation (8.06), spider mite infestation (4.51), little leaf incidence (2.60) and phomopsis blight (8.86). Cluster III registered highest mean value for average fruit weight (141.78) and fruit diameter (7.71), cluster VI registered highest mean values for fruit length (18.62) and plant height (90.69), whereas cluster II had least mean value for unmarketable yield per plant (0.11). Five traits namely fruit weight (44.67), ascorbic acid content (37.00), number of leaves per plant $(6.33 \%)$, fruit diameter $(6.00 \%)$ and fruit length (3.00 $\%)$, contributed $97 \%$ towards total genetic diversity. 


\section{Introduction}

Brinjal (Solanum melongena L.), belonging to the angiospermic family 'Solanaceae', is an often cross-pollinated crop with crosspollination reported as high as $48 \%$ (Madhavi, 2015). A great diversity in forms, shapes and colours of brinjal are found throughout Indian subcontinent, suggesting that this area is an important centre of variation and possibly of origin (Vavilov, 1951). It is one of the most popular and versatile vegetable crop adapted to different agro-climatic regions of India and can be grown throughout the year right from sea level to snowline. India is the second largest producer of brinjal in the world next to China and produces 13557.8 '000 MT from an area of 711.3 ' 000 ha (NHB, 2014). Brinjal crop is under constant assault by biotic agents including various pathogens and insect herbivores, with enormous economic and ecological impact and the most extensive damage to brinjal fruit yield is caused by fruit $\&$ shoot borer and diseases like phomopsis blight and little leaf which reduces the yield and inflicts colossal loss in production. There is an utmost need for development of high yielding varieties and hybrids for specific environments (Vaddoria et al., 2009).

Selection of parents identified on the basis of divergence analysis would be more promising for a hybridization programme (Ahmad et al., 2014). It was observed that more diverse the parents, greater is the chances of obtaining high heterotic $\mathrm{F}_{1}$ 's and broad spectrum of variability in the segregating generation (Arunachalam, 1981). Genetic divergence plays a pivotal role in assessment of diversity and establishing relationships among cultivated species and thus facilitates the establishment of conservation strategies, the use of genetic resources in breeding programmes, and the study of crop evolution (Mishra et al., 2013). Therefore, brinjal having a greater variation with regard to fruit yield and its component traits, genetic divergence based on Mabalanobis $\mathrm{D}^{2}$ technique as described by Rao (1952) appears to be a fruitful approach which is based on multivariate analysis and serves to be a good index of genetic diversity. Existence of large variability among the genotypes necessitates further analysis of genetic divergence (Mehta et al., 2004).

\section{Materials and Methods}

The experimental field of Division of Vegetable Science and Floriculture, SKUAST, Jammu is situated at $32^{\circ} 40^{\prime} \mathrm{N}$ latitude and $74^{\circ}$ $58^{\prime}$ E longitude and has an elevation of $332 \mathrm{~m}$ above mean sea level. Agro-climatically, the location represents Zone $\mathrm{V}$ of Jammu and Kashmir and is characterized by subtropical climate. The place experiences hot dry summer, hot and humid rainy season and cold winter months, the maximum temperature goes up to $45^{\circ} \mathrm{C}$ during summer (May to June) and minimum temperature falls to $1^{\circ} \mathrm{C}$ during winters. The mean annual rainfall is about 1000-1200 $\mathrm{mm}$.

The experimental material comprised of 25 diverse brinjal genotypes including $10 \quad F_{1}$ hybrids namely, Rajni, PPL-74, Nav Kiran Improved, Sandhya, MH-80, Chhaya, PBH-3, Nisha Improved, Shamli, and Abhishek, and fifteen open pollinated varieties namely Punjab Sadabahar, Arka Shirish, Arka Kusumkar, Arka Keshav, Arka Nidhi, Arka Neelkanth, Pusa Shyamala, Pusa Kranti, Pusa Ankur, Pusa Uttam, Pusa Purple Long, Pusa Purple Round, Pusa Purple Cluster, BR-14 and Puneri Kateri collected from different parts of the country. The experimental material was tested under six environments comprising of three sowing seasons spreading across two years during 2013-2014 and 2014-2015 i. e., $\mathrm{E}_{1}$-autumn-winter, 2013; $\mathrm{E}_{2}$ - spring-summer, 2014; $\mathrm{E}_{3}$-rainy, 2014; $\mathrm{E}_{4}$ - autumn-winter, 2014; $\mathrm{E}_{5}$ - spring-summer, 2015 and $\mathrm{E}_{6}$-rainy, 
2015. The individual experiment was conducted in Randomized Block Design with three replications. The uniform, healthy seedlings were transplanted on ridges maintaining inter and intra row spacing of 90 $\mathrm{cm} \times 60 \mathrm{~cm}$, respectively. All the recommended package of practices for raising a healthy crop were followed. Observations were recorded on five randomly selected plants of each genotype in each replication for various traits. The data thus obtained was analyzed as per method given by Mahalanobis, 1936. Criteria Toucher (Rao, 1952) was used for determining the groups and clustering was done accordingly. Average inter and intra cluster distances were estimated as per method given by Singh and Chaudhary, 1985.

\section{Results and Discussion}

Twenty five diverse genotypes (15 open pollinated varieties and 10 hybrids) were grouped into six clusters on the basis of $\mathrm{D}^{2}$ values, suggesting adequate genetic diversity for selecting superior and diverse parents which can be suitable exploited for any brinjal improvement programme. The perusal of data (Table 1) depicted that cluster VI had maximum number of genotypes (7) namely Arka Shirish, Arka Kusumkar, Pusa Shyamla, Pusa Purple Long, Pusa Purple Cluster, Puneri Kateri and Arka Neelkanth, followed by cluster III (5 genotypes) namely Rajni, Sandhya, PBH-3, Pusa Kranti and Pusa Ankur, cluster IV (4 genotypes) and cluster V (4 genotypes).

No association between genetic diversity and geographical diversity was indicated by the clustering pattern. The results are in accordance with the earlier work of Madhavi et al., 2015; Ahmed et al., 2014; Kumar et al., 2013; Mishra et al., 2013; Rathi et al., 2011 and Mehta and Sahu, 2009 in brinjal. The genotypes that originated in one region had been distributed into different clusters, indicating that genotypes with same geographic origin could have undergone change for different characters under selection. This could be due to selection pressure, genetic drift and introduction, which help in creating more diversity rather than genetic distance.

The intra and inter cluster values (Table 2) depicted that cluster III had maximum intra cluster distance $i$. e., 12.636, followed by cluster II (7.303) and cluster I (6.044), suggesting considerable genetic divergence among the genotypes of the respective clusters and the genotypes from within the clusters can be chosen as parents for any hybridization programme. The relative distance of each cluster from the other cluster i.e., inter-cluster distance depicts greater divergence among the clusters. In the present study maximum intercluster distance (Table 2) was recorded between cluster IV and cluster VI (53.430) followed by cluster III and cluster IV (51.078) and cluster I and cluster III (36.610), suggesting greater diversity between genotypes belonging to respective pairs of clusters. The genotypes between the respective farthest clusters can be exploited for hybridization programme.

The cluster means of genotypes revealed considerable genetic difference between the groups (Table 3 ). The genotypes in cluster IV were having highest mean values for days to $50 \%$ flowering (55.39), days to first picking (77.14), number of fruits per plant (46.87), number of leaves per plant (56.98), number of primary branches (6.22), marketable yield per plant (1.70), fruit yield per plant (1.92), fruit yield per hectare (202.95), ascorbic acid content (13.55), total phenol content (1.25) and least mean values for shoot borer infestation (8.73), fruit borer infestation (8.06), spider mite infestation (4.51), little leaf incidence (2.60) and phomopsis blight (8.86). 
Table.1 Clustering pattern of 25 genotypes of brinjal based on $\mathrm{D}^{2}$ statistics

\begin{tabular}{|c|c|c|c|}
\hline Cluster & $\begin{array}{l}\text { Number of } \\
\text { genotypes }\end{array}$ & Genotypes & Source \\
\hline I & 3 & $\begin{array}{l}\text { Pusa Uttam } \\
\text { PPR } \\
\text { BR-14 }\end{array}$ & $\begin{array}{l}\text { IARI, New Delhi } \\
\text { IARI, New Delhi } \\
\text { IIVR, Varanasi }\end{array}$ \\
\hline II & 2 & $\begin{array}{l}\text { PPL-74 } \\
\text { Shamli }\end{array}$ & $\begin{array}{l}\text { Century Seeds } \\
\text { Seminis Seeds }\end{array}$ \\
\hline III & 5 & $\begin{array}{l}\text { Rajni } \\
\text { Sandhya } \\
\text { PBH-3 } \\
\text { Pusa Kranti } \\
\text { Pusa Anku }\end{array}$ & $\begin{array}{l}\text { Nunhems Seeds } \\
\text { Nunhems Seeds } \\
\text { PAU, Ludhiana } \\
\text { IARI, New Delhi } \\
\text { IARI, New Delhi }\end{array}$ \\
\hline IV & 4 & $\begin{array}{l}\text { Nisha Improved } \\
\text { Punjab Sadabahar } \\
\text { ArkaKeshav } \\
\text { ArkaNidhi }\end{array}$ & $\begin{array}{l}\text { Century Seeds } \\
\text { PAU, Ludhiana } \\
\text { IIHR, Bangaluru } \\
\text { IIHR, Bangaluru }\end{array}$ \\
\hline $\mathbf{V}$ & 4 & $\begin{array}{l}\text { Navkiran Improved } \\
\text { MH-80 } \\
\text { Chhaya } \\
\text { Abhishek }\end{array}$ & $\begin{array}{l}\text { Sungrow Seeds } \\
\text { Mahycco Seeds } \\
\text { Nunhems Seeds } \\
\text { Nunhems Seeds }\end{array}$ \\
\hline VI & 7 & $\begin{array}{l}\text { ArkaShirish } \\
\text { ArkaKusumkar } \\
\text { Pusa Shyamla } \\
\text { PPL } \\
\text { PPC } \\
\text { PuneriKateri } \\
\text { ArkaNeelkanth }\end{array}$ & $\begin{array}{l}\text { IIHR, Bangaluru } \\
\text { IIHR, Bangaluru } \\
\text { IARI, New Delhi } \\
\text { IARI, New Delhi } \\
\text { IARI, New Delhi } \\
\text { Safal Seeds Co., Jalna } \\
\text { IIHR, Bangaluru }\end{array}$ \\
\hline
\end{tabular}

Table.2 Average intra (bold) and inter cluster distance values among clusters in brinjal

(Solanum melongena L.)

\begin{tabular}{|l|c|c|c|c|c|c|}
\hline Cluster & I & II & III & IV & V & VI \\
\hline I & $\mathbf{6 . 0 4 4}$ & & & & & \\
\hline II & 18.999 & $\mathbf{7 . 3 0 3}$ & & & & \\
\hline III & 36.610 & 33.909 & $\mathbf{1 2 . 6 3 6}$ & & & \\
\hline IV & 14.763 & 31.874 & 51.078 & $\mathbf{3 . 1 0 8}$ & & \\
\hline V & 10.841 & 16.379 & 16.791 & 22.257 & $\mathbf{0 . 0 0 0}$ & \\
\hline VI & 33.710 & 24.187 & 26.203 & 53.430 & 29.462 & $\mathbf{0 . 0 0 0}$ \\
\hline
\end{tabular}


Table.3 Cluster means for various quantitative, qualitative and biotic stress traits in 25 genotypes of brinjal (Solanum melongena L.)

\begin{tabular}{|c|c|c|c|c|c|c|c|}
\hline \multirow[t]{2}{*}{ S No. } & \multirow[t]{2}{*}{ Traits } & \multicolumn{6}{|c|}{ Cluster Means } \\
\hline & & I & II & III & IV & V & VI \\
\hline 1. & Days to $50 \%$ flowering & 60.94 & 65.31 & 59.67 & 55.39 & 55.78 & 72.72 \\
\hline 2. & Days to first picking & 85.31 & 90.50 & 83.45 & 77.14 & 85.22 & 99.44 \\
\hline 3. & Fruit length $(\mathrm{cm})$ & 12.67 & 7.18 & 9.01 & 14.39 & 8.98 & 18.62 \\
\hline 4. & Fruit diameter $(\mathrm{cm})$ & 2.43 & 3.39 & 7.71 & 2.55 & 7.14 & 2.99 \\
\hline 5. & Number of fruits/plant & 16.38 & 11.58 & 10.41 & 46.87 & 15.79 & 6.78 \\
\hline 6. & Average fruit weight (g) & 55.67 & 40.80 & 141.78 & 40.46 & 90.61 & 104.67 \\
\hline 7. & Number of leaves per plant & 34.79 & 33.80 & 38.47 & 56.98 & 33.86 & 29.62 \\
\hline$\overline{8 .}$ & Plant height $(\mathrm{cm})$ & 67.37 & 68.56 & 73.40 & 77.87 & 73.84 & 90.69 \\
\hline 9. & Number of primary branches per plant & 4.54 & 4.72 & 5.34 & 6.22 & 5.71 & 4.91 \\
\hline 10. & Marketable yield per plant $(\mathrm{kg})$ & 0.74 & 0.39 & 1.13 & 1.70 & 1.16 & 0.57 \\
\hline 11. & Unmarketable yield per plant $(\mathrm{kg})$ & 0.17 & 0.11 & 0.31 & 0.18 & 0.30 & 0.15 \\
\hline 12. & Fruit yield per plant $(\mathrm{kg})$ & 0.91 & 0.47 & 1.45 & 1.92 & 1.46 & 0.74 \\
\hline 13. & Fruit yield (Q/ha) & 94.55 & 46.36 & 135.28 & 202.95 & 136.89 & 77.07 \\
\hline 14. & Ascorbic acid content $(\mathrm{mg} / 100 \mathrm{~g})$ & 13.26 & 9.52 & 10.35 & 13.55 & 12.70 & 7.90 \\
\hline 15. & Total phenol content $(\mathrm{mg} / 100 \mathrm{~g})$ & 1.14 & 0.85 & 0.90 & 1.25 & 0.87 & 0.74 \\
\hline 16. & Shoot borer infestation (\%) & 15.53 & 17.82 & 20.02 & 8.73 & 18.41 & 16.58 \\
\hline 17. & Fruit borer infestation (\%) & 14.79 & 17.27 & 19.07 & 8.06 & 17.60 & 16.07 \\
\hline 18. & Spider mite infestation (\%) & 5.38 & 10.37 & 13.40 & 4.51 & 14.58 & 14.93 \\
\hline 19. & Little leaf incidence (\%) & 5.47 & 6.30 & 8.02 & 2.60 & 6.94 & 10.07 \\
\hline 20. & Phomopsis blight incidence (\%) & 18.45 & 17.71 & 17.13 & 8.86 & 17.17 & 23.85 \\
\hline
\end{tabular}

Table.4 Per cent contribution of various traits to total divergence in brinjal (Solanum melongena L.)

\begin{tabular}{|c|l|c|}
\hline S. No. & \multicolumn{1}{|c|}{ Trait } & \% contribution \\
\hline $\mathbf{1}$ & Days to 50\% Flowering & 0.00 \\
\hline $\mathbf{2}$ & Days to 1st Picking & 0.67 \\
\hline $\mathbf{3}$ & Fruit Length (cm) & 3.00 \\
\hline $\mathbf{4}$ & Fruit Diameter $(\mathrm{cm})$ & 6.00 \\
\hline $\mathbf{5}$ & No. of Fruits/ Plant & 0.67 \\
\hline $\mathbf{6}$ & Fruit Weight (kg) & 44.67 \\
\hline $\mathbf{7}$ & No. of Leaves/ Plant & 6.33 \\
\hline $\mathbf{8}$ & Plant Height (cm) & 0.00 \\
\hline $\mathbf{9}$ & No. of Branches/ Plant & 0.00 \\
\hline $\mathbf{1 0}$ & Marketable Yield/ Plant $(\mathrm{kg})$ & 0.67 \\
\hline $\mathbf{1 1}$ & Unmarketable Yield/ Plant $(\mathrm{kg})$ & 0.00 \\
\hline $\mathbf{1 2}$ & Fruit Yield/ Plant (kg) & 0.00 \\
\hline $\mathbf{1 3}$ & Fruit Yield/ Hectare (q) & 0.00 \\
\hline $\mathbf{1 4}$ & Ascorbic Acid (mg/100g) & 37.00 \\
\hline $\mathbf{1 5}$ & Total Phenol (mg/100g) & 0.67 \\
\hline $\mathbf{1 6}$ & Shoot Borer infestation $(\%)$ & 0.00 \\
\hline $\mathbf{1 7}$ & Fruit Borer infestation $(\%)$ & 0.00 \\
\hline $\mathbf{1 8}$ & Spider Mite infestation $(\%)$ & 0.00 \\
\hline $\mathbf{1 9}$ & Little Leaf incidence $(\%)$ & 0.00 \\
\hline $\mathbf{2 0}$ & Phomopsis Blight incidence $(\%)$ & 0.33 \\
\hline
\end{tabular}


Fig.1 Ward's Minimum Variance Dendogram

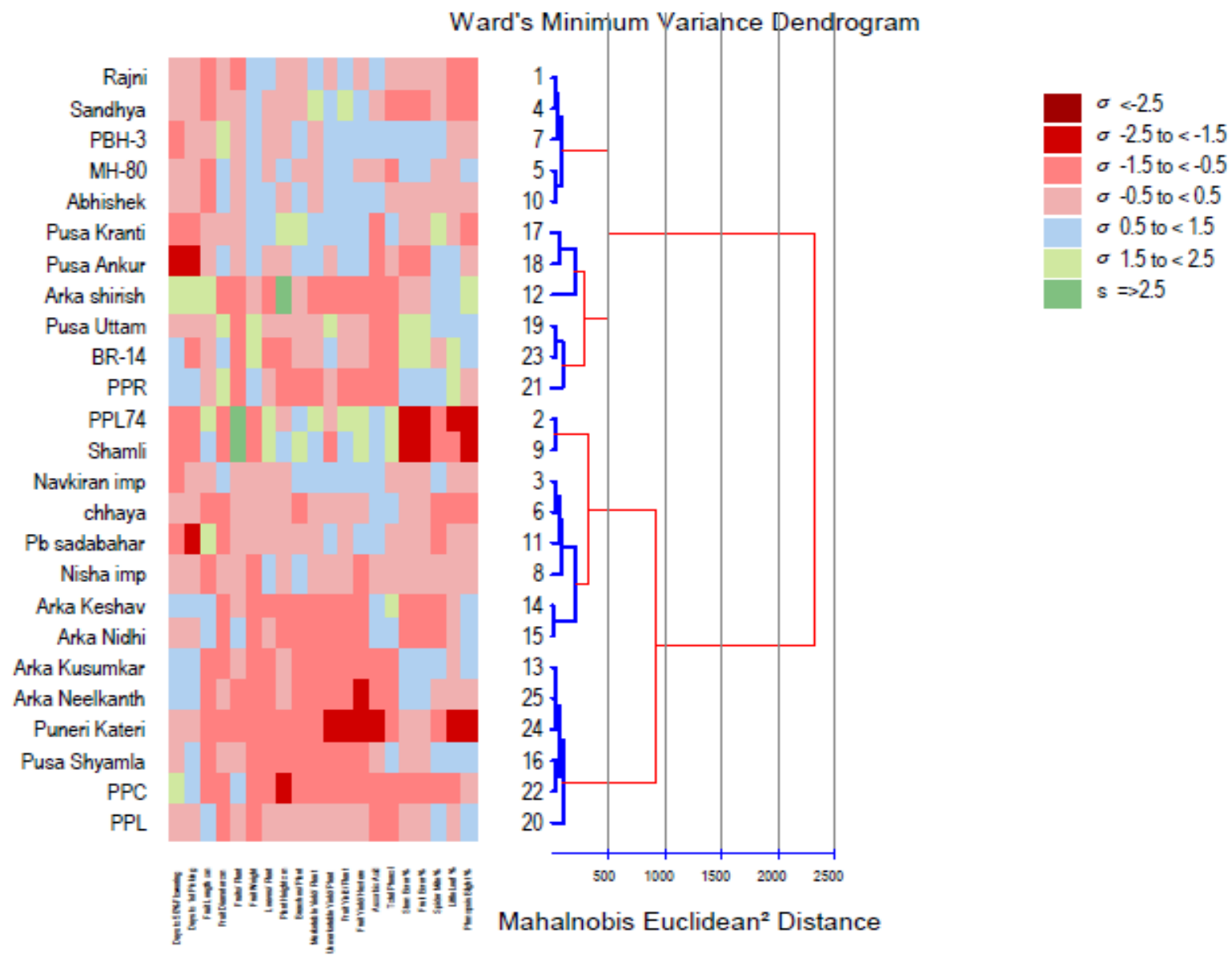

Cluster III registered highest mean value for average fruit weight (141.78) and fruit diameter (7.71), cluster VI registered highest mean values for fruit length (18.62) and plant height (90.69), whereas cluster II had least mean value for unmarketable yield per plant (0.11). From the present investigation it can be concluded that intercrossing of genotypes from these diverse clusters may result in wide array of variability for having effective selection for these characters.

These results are in consonance with the findings of the earlier work of Madhavi et al., 2015; Ahmed et al., 2014; Kumar et al., 2013; Mishra et al., 2013; Rathi et al., 2011 and Mehta and Sahu, 2009 in brinjal. Inter crossing of divergent groups would lead to greater opportunity for crossing over, which may release hidden variability by breaking linkage (Thoday, 1969). Hence these genotypes can be used in singly as well as multiple crossing programmes for the development of promising hybrids.

Per cent (\%) contribution of various traits towards total genetic diversity (Table 4) revealed that maximum contribution was of fruit weight (44.67), followed by ascorbic acid content (37.00), number of leaves per plant $(6.33 \%)$, fruit diameter $(6.00 \%)$ and fruit length (3.00\%), contributing $97 \%$ of the total genetic diversity. The observations were in conformity with the results obtained by Madhavi et al., 2015 and Kumar et al., 2013 in brinjal. 


\section{References}

Ahmed, N., Singh, S.R., Lal, S., Mir, K.A., Asima Amin, Habib, K. and Salmani, M. 2014. Assessment of genetic diversity in brinjal genotypes using multivariate analysis. Indian Journal of Horticulture. 71(4): 494-498.

Arunachalam, V. 1981. Genetic distances in plant breeding. Indian Journal of Genetics. 41: 226-236.

Babu, R. B. and Patil, R.V. 2004. Genetic divergence in brinjal. Vegetable Science. 31(2): 125-128.

Indian Horticulture Database (2014). Data on area, production and productivity on brinjal in India. National Horticulture Board, New Delhi.

Kumar, S.R., Arumugam, T. and Anandakumar, C.R. 2013. Genetic diversity in eggplant (Solanum melongena L.). Plant Gene and Trait. 4 (2): 4-8.

Madhavi, N., Mishra, A.C. Pushpavathi, Y. and Kumari, V.L.P. 2015. Genetic diversity in brinjal (Solanum melongena L.) under temperate hills of Uttarakhand, India. Plant Archives. 15(2): 1107-1110.

Mahalanobis, P.C. 1936. On the generalized distance in statistics. Proc. Nat. Inst.Sci. Indi., 2: 49-55.

Mehta, A.K. and Sahu, M. 2009. Genetic divergence in brinjal (Solanum melongena L.). International Journal of Plant Science. 4: 123-124.
Mehta, D.R., Golani, I.J., Pandya, H.M., Patel, R.K. and Naliyadhara, M.V. 2004. Genetic diversity in brinjal (Solanum melongena L.). Vegetable Science. 31(2): 142-145.

Mishra, S.P., Jha, Ashok, Kushwah, M.K. and Mishra, V.K. 2013. Genetic divergence in eggplant (Solanum melongena L.). Vegetable Science. 40(2): 219-220.

Muniappan, S., Saravanan, K. and Ramya, B. 2010. Studies on genetic divergence and variability for certain economic characters in eggplant (Solanum melongena L.). Electronic Journal of Plant Breeding. 1(4): 462-465.

Rao, C.R. 1952. Advanced Statistical Methods in Biometrical research. John Wiley and Sons New York.

Rathi, Saurabh, Kumar, Ravinder, Munshi, A.D. and Verma, Manjusha. 2011. Breeding potential of brinjal genotypes using $\mathrm{D}^{2}$ analysis. Indian Journal of Horticulture. 68(3): 328-331.

Singh, R.K. and Choudhary, B.D. 1985. Diametrical Methods in Quantitative Genetic Analysis. Kalyani Publishers, New Delhi, 318 p.

Thoday, J.M. 1969. Effect of disruptive selection III coupling and repulsion. Heredity. 14: 35-39.

Vadodaria, M.A., Kulkarni, G.H. Madariya, R.B. and Dobariya, K.L. 2009. Stability for fruit yield \& its component traits in brinjal Crop Improvement. 36(1): 81-87.

\section{How to cite this article:}

Anil Bhushan, R. K. Samnotra and Sanjeev Kumar. 2018. Genetic Divergence Studies in Brinjal (Solanum melongena L.) under Subtropical Plains of North-Western Himalayan Region. Int.J.Curr.Microbiol.App.Sci. 7(06): 1647-1653. doi: https://doi.org/10.20546/ijcmas.2018.706.196 